\title{
PERBEDAAN MOTIVASI DAN HASIL BELAJAR PESERTA DIDIK KELAS XI IPA YANG DIBELAJARKAN MODEL PEMBELAJARAN BERBASIS MASALAH DENGAN INKUIRI TERBIMBING DI SMA NEGERI 1 MAJENE PADA MATERI POKOK SISTEM KOLOID
}

\author{
Asnia, Sudding ${ }^{2}$, Jusniar ${ }^{3}$ \\ 2,3 Dosen Pascasarjana Universitas Negeri Makassar, Makassar \\ Email:asnia_chemistry@yahoo.co.id
}

\begin{abstract}
ABSTRAK
Jenis penelitian ini adalah penelitian eksperimen semu (quasi eksperimen) yang bertujuan untuk mengetahui ada tidaknya perbedaan peningkatan motivasi dan hasil belajar antara peserta didik yang dibelajarkan model pembelajaran berbasis masalah dengan inkuiri terbimbing di SMA Negeri 1 Majene. Penelitian ini dilaksanakan di SMA Negeri 1 Majene. Populasi penelitian adalah peserta didik kelas XI IPA semester genap tahun pelajaran 2014/2015, terdiri dari 4 kelas. Teknik pengambilan sampel menggunakan simple random sampling. Instrumen untuk mengetahui motivasi dan hasil belajar digunakan pemberian angket dan tes hasil belajar di awal dan di akhir pembelajaran. Analisis data terdiri dari analisis statistik deskriptif untuk mendeskripsikan motivasi dan hasil belajar dan analisis statistik inferensial untuk menguji hipotesis penelitian dengan menggunakan uji t. Hasil penelitian menunjukkan bahwa: (1) Peningkatan motivasi belajar peserta didik yang dibelajarkan model pembelajaran berbasis masalah dan inkuiri terbimbing sama-sama kategori tinggi yaitu 0,78 dan 0,82 , (2) Peningkatan hasil belajar peserta didik yang dibelajarkan model pembelajaran berbasis masalah dan inkuiri terbimbing sama-sama kategori tinggi yaitu 0,72 dan 0,74, (3) Pengujian hipotesis pertama diperoleh $p$-value 0,095 > 0,05 , (4) Pengujian hipotesis kedua diperoleh $p$-value 0,545>0,05. Pada analisis statistik deskriptif terdapat perbedaan peningkatan motivasi dan hasil belajar peserta didik yang dibelajarkan model pembelajaran berbasis masalah dengan inkuiri terbimbing. Sedangkan pada analisis statistik inferensial menunjukkan bahwa tidak terdapat perbedaan yang signifikan peningkatan motivasi dan hasil belajar peserta didik yang dibelajarkan model pembelajaran berbasis masalah dengan inkuiri terbimbing.
\end{abstract}

Kata kunci: Berbasis Masalah, Inkuiri Terbimbing, Motivasi dan Hasil Belajar.

\begin{abstract}
The research was quasi-experiment research which aimed to discover whether there were differences of motivation improvement and learning result between the students who taught by problem based leaning model and guided inquiry in SMAN 1 Majene. The research was conducted in SMAN 1 Majene. The population of the research was the students of class XI IPA of the second semester of academic year 2014/201 5, which consisted of 4 classes. The sample was obtained by employing simple random sampling technique. The instruments used to discover the motivation and learning result were questionnaire and learning result test given at the beginning and at the end of learning. The data analysis consisted of descriptive statistics analysis to describe motivation and learning result and inferential statistics analysis to test the research hypothesis by using t-test. The results of the research showed that: (1) the improvement of learning motivation of the students who taught by using problem based learning model and guided inquiry were both in high category which shown 0.78 and $0.82,(2)$
\end{abstract}


the improvement of learning result of the students who taught by using problem based learning model and guided inquiry were both in high category which shown 0.72 and $0.74,(3)$ first hypothesis test gained the score of p-value $0.095>0.05$, (4) second hypothesis test gained the score of $\mathrm{p}$-value $0.545>0.05$. In descriptive statistics analysis, there were differences of improvement of motivation and learning result of the students who taught by using problem based learning model and guided ìnquiry. While in inferential statistics analysis showed that there was no significant difference of motivation and learning result of the students who taught by using problem based feaming model and guided inquiry.

Keywords: Problem Based, Guided Inquiry, Motivation, and Learning Result.

\section{PENDAHULUAN}

Kimia merupakan bagian dari sains yang materinya terdiri dari fakta, konsep dan hukum dasar kimia. Hal ini menyebabkan muncul anggapan dikalangan peserta didik bahwa ilmu kimia sulit dimengerti karena terkadang pembahasannya bersifat teoritik, banyaknya hukum-hukum yang terdapat pada materi saling terkait antara satu dengan yang lain, konsep-konsep yang umumnya dinyatakan dalam rumusan matematis dan tingkat kesulitan tiap materi pelajaran tidaklah sama, hal ini membuat peserta didik mengeluh dan kurang tertarik untuk mempelajari kimia sehingga mempengaruhi motivasi dan hasil belajar peserta didik.

Pada saat pembelajaran berlangsung akan terjadi hubungan timbal balik antara guru dan peserta didik yang beraneka ragam, oleh karena itu guru harus lebih kreatif dalam melaksanakan pembelajaran, menciptakan suasana belajar yang menyenangkan pada diri peserta didik, membuat peserta didik lebih berpartisipasi aktif dalam pembelajaran sehingga dapat meningkatkan motivasi belajar peserta didik. Sebagaimana dikemukakan Prayitno dalam Karim (2010) menyatakan bahwa motivasi belajar adalah dorongan dalam diri peserta didik yang menimbulkan kegiatan ke arah belajar untuk mencapai tujuan yang dikehendaki. Motivasi dapat memberikan semangat yang luar biasa terhadap seseorang untuk berprilaku dan dapat memberikan arah dalam belajar.

Profesionalisme seorang guru bukan hanya mengembangkan ilmu pengetahuan, akan tetapi lebih kepada kemampuannya untuk mencapai keberhasilan sesuai tujuan pembelajaran. Salah satu caranya adalah menerapkan model pembelajaran yang sesuai dengan materi pelajaran. Model pembelajaran adalah pola yang digunakan sebagai pedoman dalam merencanakan pembelajaran. Model pembelajaran diartikan sebagai kerangka konseptual yang melukiskan prosedur yang sistematis dalam mengorganisasikan pengalaman belajar untuk mencapai tujuan belajar (Soekamto dalam Trianto, 2011).

Kurikulum 2013 menekankan pada keseimbangan antara keterampilan, penalaran dan pengembangan sikap. Aktifitasnya terdiri atas mengamati, menanya, mengumpulkan data, mengasosiasi dan mengkomunikasikan materi yang telah dipelajari. Diantara model pembelajaran yang dapat meningkatkan hasil belajar peserta didik dan sejalan dengan tujuan kurikulum 2013 adalah model pembelajaran berbasis masalah dan model pembelajaran inkuiri.

Pembelajaran berbasis masalah berpusat pada peserta didik (student centered approach) karena peserta didik memiliki tanggung jawab masing-masing dalam mencari informasi yang relevan terhadap masalah kemudian barulah mereka mendiskusikan dengan teman 
kelompoknya untuk menemukan sebuah solusi (Savery, 2006).

Sebagaimana penelitian yang dilakukan oleh Hadijah (2014) menyatakan bahwa model pembelajaran berbasis masalah dapat meningkatkan motivasi dan hasil belajar peserta didik.

Pembelajaran inkuiri merupakan bentuk dari pendekatan pembelajaran yang berbasis kontekstual dan berorientasi kepada peserta didik (student centered approach) untuk mencari dan menemukan sendiri jawaban dari suatu masalah yang dipertanyakan (Sanjaya, 2010). Inkuiri yang terarah (terbimbing) adalah inkuiri yang banyak dicampuri oleh guru. Guru banyak mengarahkan dan memberikan petunjuk baik lewat prosedur yang lengkap dan pertanyaan-pertanyaan pengarahan selama proses inkuiri (Paul S, 2007). Sebagaimana penelitian yang dilakukan oleh Trisulsiati (2010) menyatakan bahwa model pembelajaran inkuiri dapat meningkatkan motivasi dan hasil belajar peserta didik.

Hasil penelitian yang telah dikemukakan tersebut di atas, menunjukkan bahwa model pembelajaran berbasis masalah dan model pembelajaran inkuiri dapat meningkatkan pemahaman peserta didik sehingga akan berdampak positif terhadap motivasi dan hasil belajarnya. Kedua model pembelajaran ini berpusat pada peserta didik (student centered approach) akan tetapi berbeda dalam hal pelaksanaannya.

Materi sistem koloid memiliki konsep-konsep yang berhubungan dalam kehidupan sehari-hari dan sebagian besar materinya bersifat teoritik. Oleh karenanya, diperlukan sebuah model pembelajaran yang mengaitkan materi dengan kehidupan sehari-hari peserta didik yang dapat meningkatkan motivasi dan hasil belajar peserta didik.

Berdasarkan hasil wawancara yang dilakukan dengan salah satu guru mata pelajaran kimia di SMA Negeri 1 Majene ditemukan bahwa tidak adanya terbuka peminatan kimia dan banyaknya peserta didik yang remedial setiap dilakukan tes di akhir pembelajaran. Hasil wawancara ini dapat disimpulkan bahwa motivasi dan hasil belajar peserta didik kelas XI IPA dalam belajar kimia masih kurang. Kurangnya motivasi belajar peserta didik mempengaruhi pula hasil belajar peserta didik. Untuk mengatasi hal tersebut, maka penulis memandang perlu diterapkan suatu model pembelajaran yang membuat peserta didik lebih aktif dalam pembelajaran serta dapat meningkatkan motivasi dan hasil belajar peserta didik dalam belajar kimia. Model pembelajaran yang dimaksud adalah model pembelajaran berbasis masalah dan pembelajaran inkuiri terbimbing.

Berdasarkan uraian di atas, maka penulis bermaksud melakukan penelitian dengan judul "Perbedaan Motivasi dan Hasil Belajar Peserta Didik Kelas XI IPA yang Dibelajarkan Model Pembelajaran Berbasis Masalah dengan Inkuiri Terbimbing di SMA Negeri 1 Majene Pada Materi Pokok Sistem Koloid.

Berdasarkan latar belakang di atas, maka rumusan masalah dalam penelitian ini adalah sebagai berikut:

1. Seberapa besar peningkatan motivasi belajar peserta didik yang dibelajarkan model pembelajaran berbasis masalah?

2. Seberapa besar peningkatan motivasi belajar peserta didik yang dibelajarkan model pembelajaran inkuiri terbimbing?

3. Seberapa besar peningkatan hasil belajar peserta didik yang dibelajarkan model pembelajaran berbasis masalah?

4. Seberapa besar peningkatan hasil belajar peserta didik yang dibelajarkan model pembelajaran inkuiri terbimbing?

5. Apakah terdapat perbedaan peningkatan motivasi belajar antara peserta didik yang dibelajarkan model pembelajaran berbasis masalah dengan inkuiri terbimbing?

6. Apakah terdapat perbedaan peningkatan hasil belajar antara peserta 
didik yang dibelajarkan model pembelajaran berbasis masalah dengan inkuiri terbimbing?

\section{METODE PENELITIAN}

\section{Jenis Penelitian}

Jenis penelitian ini merupakan penelitian eksperimen semu (quasy eksperimen) dengan menggunakan dua kelompok yaitu kelompok (eksperimen 1) dan kelompok (eksperimen 2). Perlakuan untuk (eksperimen 1) adalah pembelajaran yang dibelajarkan model pembelajaran berbasis masalah. Perlakuan untuk (eksperimen 2) adalah pembelajaran yang dibelajarkan model pembelajaran inkuiri terbimbing.

2. Desain Penelitian

Desain yang digunakan dalam penelitian ini adalah "Pretest Posttest Control Group Design" sebagaimana pada Tabel .1.

Tabel.1 Desain Penelitian

\begin{tabular}{cccc}
\hline Kelompok & Pretest & Treatment & Posttest \\
\hline Eksperimen & $\mathrm{O}_{1}$ & $\mathrm{X}_{1}$ & $\mathrm{O}_{2}$ \\
1 & $\mathrm{O}_{3}$ & & $\mathrm{O}_{4}$ \\
Eksperimen & $\mathrm{O}_{5}$ & $\mathrm{X}_{2}$ & $\mathrm{O}_{6}$ \\
2 & $\mathrm{O}_{7}$ & & $\mathrm{O}_{8}$ \\
\hline
\end{tabular}

Sumber: (Sugiyono, 2010)

Keterangan:

$\mathrm{T}_{1}=$ Pembelajaran yang dibelajarkan model pembelajaran berbasis masalah (eksperimen 1)

$\mathrm{T}_{2}=$ Pembelajaran yang dibelajarkan model pembelajaran inkuiri terbimbing (eksperimen 2)

$\mathrm{O}_{1}=$ Pretest hasil belajar peserta didik (eksperimen 1)

$\mathrm{O}_{2}=$ Posttest hasil belajar peserta didik (eksperimen 1)

$\mathrm{O}_{3}=$ Pretest motivasi belajar peserta didik (eksperimen 1)

$\mathrm{O}_{4}=$ Posttest motivasi belajar peserta didik (eksperimen 1)

$\mathrm{O}_{5}=$ Pretest hasil belajar peserta didik (eksperimen 2)
$\mathrm{O}_{6}=$ Posttest hasil belajar peserta didik (eksperimen 2)

$\mathrm{O}_{7}=$ Pretest motivasi belajar peserta didik (eksperimen 2)

$\mathrm{O}_{8}=$ Posttest motivasi belajar peserta didik (eksperimen 2)

3. Variabel Penelitian

Penelitian ini menggunakan variabel

bebas (independent) yaitu model pembelajaran berbasis masalah dan model pembelajaran inkuiri terbimbing. Variabel terikat (dependent) yaitu motivasi dan hasil belajar peserta didik.

4. Populasi dan Sampel

Populasi dalam penelitian ini adalah seluruh peserta didik kelas XI IPA SMA Negeri 1 Majene pada tahun pelajaran 2014/2015 yang terdiri dari 4 kelas dengan jumlah 102 peserta didik.

Pengambilan sampel dengan sampel acak (random sampling) dengan asumsi bahwa populasi bersifat homogen. Dari hasil pengambilan sampel ditetapkan kelas XI IPA 1 sebanyak 22 peserta didik sebagai kelas yang dibelajarkan model pembelajaran berbasis masalah dan XI $\mathrm{IPA}_{3}$ sebanyak 26 peserta didik sebagai kelas yang dibelajarkan model pembelajaran inkuiri terbimbing.

5. Instrumen Penelitian

Instrumen yang digunakan dalam penelitian ini meliputi:

Instrumen motivasi belajar berupa angket pengukuran motivasi belajar sebelum dan sesudah dibelajarkan model pembelajaran berbasis masalah dan model pembelajaran inkuiri terbimbing. Angket motivasi terdiri dan 20 item pernyataan mengacu pada indikator motivasi yaitu perhatian (attention), relevansi (relevance), percaya diri (confidence), kepuasan (satisfaction). Sebelum digunakan, instrumen angket motivasi terlebih dahulu divalidasi oleh dua orang pakar.

Instrumen hasil belajar merupakan tes untuk memperoleh data tentang hasil belajar yang diberikan sebelum dan sesudah pembelajaran dilakukan. Instrumen yang digunakan berupa tes hasil 
belajar yang dibuat oleh penulis berbentuk pilihan ganda sebanyak 25 item soal. Sebelum digunakan, terlebih dahulu diuji validitas isi oleh pakar yang bertujuan untuk mengetahui sejauh mana instrumen tersebut mencakup isi tes yang dikehendaki.

6. Teknik Pengumpulan Data

Teknik pengumpulan data dalam penelitian ini yaitu:

Data motivasi belajar peserta didik diambil dengan menggunakan angket motivasi belajar yang diberikan sebelum dan sesudah pembelajaran pada kedua kelas eksperimen yakni yang dibelajarkan model pembelajaran berbasis masalah dengan inkuiri terbimbing.

Data hasil belajar peserta didik diambil dengan menggunakan tes hasil belajar yang diberikan sebelum dan sesudah pembelajaran pada kedua kelas eksperimen yakni yang dibelajarkan model pembelajaran berbasis masalah dengan inkuiri terbimbing.

7. Teknik Analisis Data

Data yang akan diperoleh dalam penelitian ini akan diolah dengan menggunakan analisis statistik deskriptif dan analisis statistik inferensial.

Analisis deskriptif dimaksudkan untuk mendeskripsikan peningkatan motivasi belajar dan hasil belajar peserta didik yang dibelajarkan model pembelajaran berbasis masalah (eksperimen 1) dengan inkuiri terbimbing (eksperimen 2).

Gain ternormalisasi merupakan perbandingan antara skor gain aktual yaitu skor gain yang diperoleh peserta didik dengan skor gain maksimum yaitu skor gain tertinggi yang mungkin diperoleh peserta didik.

a. Motivasi Belajar

Analisis data skor motivasi peserta didik untuk belajar kimia yaitu: 1) menghitung skor motivasi, 2) menghitung persentase motivasi, 3) menghitung ratarata gain motivasi.

Analisis dilakukan dengan menggunakan model skala Likert. Jawaban untuk pernyataan positif dengan skor, $4=$ sangat setuju, $3=$ setuju, 2 = kurang setuju, $1=$ tidak setuju. Sedangkan jawaban untuk pernyataan negatif dengan skor, $4=$ tidak setuju, $3=$ kurang setuju, $2=$ setuju, $1=$ sangat setuju. Jika semua responden memberikan jawaban bernilai 4 memenuhi skor maksimal 80 dan jika semua responden memberikan jawaban 1 memenuhi skor minimal 20.

Besarnya peningkatan motivasi sebelum dan sesudah pembelajaran dihitung dengan rumus gain ternormalisasi setiap didik berikut dalam

$$
g=\frac{S_{\text {post }}-S_{\text {pre }}}{S_{\text {maks }}-S_{\text {pre }}}
$$

peserta sebagai (Hake Yanti,
Keterangan :

$\mathrm{g} \quad=$ gain ternormalisasi

$\mathrm{S}_{\text {pre }} \quad=$ skor pretest

$\mathrm{S}_{\text {post }}=$ skor posttest

$\mathrm{S}_{\text {maks }}=$ skor maksimum ideal

Rata-rata gain ternormalisasi dapat ditentukan dengan rumus sebagai berikut:

Keterangan :

$$
\begin{aligned}
<\mathrm{g}> & <g>=\frac{<S_{\text {post }}>-<S_{\text {pre }}>}{<S_{\text {maks }}>-<S_{\text {pre }}>} \\
& =\text { gain ternormalisasi } \\
\left\langle\mathrm{S}_{\text {pre }}>\right. & =\text { skor pretest } \\
\left\langle\mathrm{S}_{\text {post }}>\right. & =\text { skor posttest } \\
\mathrm{S}_{\text {maks }} & =\text { skor maksimum ideal }
\end{aligned}
$$

Untuk klasifikasi

Gain

Ternormalisasi terlihat pada Tabel 3.2.

Tabel.2 Klasifikasi Gain Ternormalisasi

\begin{tabular}{cc}
\hline $\begin{array}{c}\text { Koefisien } \\
\text { Normalisasi } \\
\text { Gain }\end{array}$ & Klasifikasi \\
\hline $\mathrm{g}<0,3$ & Rendah \\
$0,3 \leq \mathrm{g}<0,7$ & Sedang \\
$\mathrm{g} \geq 0,7$ & Tinggi \\
\hline
\end{tabular}

Mengacu pada rentang skor persentase motivasi belajar peserta didik, maka dibuat 
5 kategori sebagai berikut: (1) sangat tinggi, (2) tinggi, (3) sedang, (4) rendah, (5) sangat rendah. Kriteria motivasi tersebut dikategorikan (modifikasi Riduwan dalam Nurlaelah, 2013) sebagaimana pada Tabel 3.3.

Tabel.3. Kriteria Motivasi

\begin{tabular}{cc}
\hline $\begin{array}{c}\text { Interval } \\
\text { Skor }\end{array}$ & Kategori \\
\hline $68-80$ & Sangat tinggi \\
$56-67$ & Tinggi \\
$44-55$ & Sedang \\
$32-43$ & Rendah \\
$20-31$ & Sangat rendah \\
\hline
\end{tabular}

b. Hasil Belajar

Hasil belajar peserta didik dianalisis secara deskriptif. Data yang diperoleh dari pretest dan posttest dianalisis untuk mengetahui peningkatan hasil belajar peserta didik dengan menggunakan rumus gain ternormalisasi.

Kriteria yang digunakan untuk menentukan kategori tes hasil belajar peserta didik dalam penelitian ini adalah merujuk pada standar yang diterapkan oleh Dinas Pendidikan dalam (Masyita, 2012) pada Tabel 4.

\begin{tabular}{cc}
\multicolumn{2}{c}{ Tabel 4 Kriteria Hasil Belajar } \\
\hline $\begin{array}{c}\text { Interval } \\
\text { skor }\end{array}$ & Kategori \\
\hline $91-100$ & Sangat tinggi \\
$75-90$ & Tinggi \\
$60-74$ & Sedang \\
$40-59$ & Rendah \\
$0-39$ & Sangat rendah \\
\hline
\end{tabular}

Kriteria ketuntasan minimal yang harus dipenuhi oleh peserta didik adalah 75. Jika seorang peserta didik memperoleh $\mathrm{KM} \geq 75$ maka peserta didik yang bersangkutan mencapai ketuntasan individu. Jika minimal $85 \%$ peserta didik mencapai skor minimal 75 maka ketuntasan klasikal tercapai.

\section{Analisis Statistik Inferensial}

Analisis ini dimaksudkan untuk menguji hipotesis yang diawali dengan menguji prasyarat statistik yaitu uji normalitas dan uji homogenitas dengan menggunakan program SPSS versi 20.

a. Uji Normalitas

Uji normalitas digunakan untuk mengetahui data berdistribusi normal atau tidak. Pada penelitian ini digunakan One Sample Kolmogrof-Smirnov dengan taraf signikan $5 \%$ atau $\alpha=0,05$. Data berdistribusi normal jika $p$-value $\geq 0,05$.

b. Uji Homogenitas

Uji ini digunakan untuk menentukan apakah sampel yang diperoleh berasal dari populasi dengan varians yang sama. Uji yang digunakan adalah uji Leneve's Test dengan taraf signifikansi $5 \%$ atau $\alpha=0,05$. Kriteria pengujian: jika signifikansi yang diperoleh $p$-value >0,05 maka secara statistik data dikatakan homogen.

\section{c. Uji Hipotesis}

Uji hipotesis pada penelitian ini dilakukan dengan menggunakan SPSS versi 20 disesuaikan dengan hipotesis yang diajukan.

1) Hipotesis Pertama

$\mathrm{H}_{0}=$ Tidak terdapat perbedaan motivasi belajar peserta didik kelas XI IPA SMA Negeri 1 Majene yang dibelajarkan model pembelajaran berbasis masalah dengan inkuiri terbimbing.

$\mathrm{H}_{1}=$ Terdapat perbedaan motivasi belajar peserta didik kelas XI IPA SMA Negeri 1 Majene yang dibelajarkan model pembelajaran berbasis masalah dengan inkuiri terbimbing.

Untuk pengujian statistiknya, hipotesis ini dirumuskan:

$$
\mathrm{H}_{0}: \mu_{1}=\mu_{2} \text { lawan } \mathrm{H}_{1}: \mu_{1} \neq \mu_{2}
$$

Keterangan:

$\mu_{1}=$ nilai rata-rata motivasi belajar peserta didik yang dibelajarkan model pembelajaran berbasis masalah.

$\mu_{2}=$ nilai rata-rata motivasi belajar peserta didik yang dibelajarkan 
model pembelajaran inkuiri terbimbing.

Kriteria pengujian: Jika $\mathrm{p}$ hit $>\mathrm{p}$ tabel $(0,05)$, maka $\mathrm{H}_{0}$ diterima $\mathrm{p}$ hit $<\mathrm{p}$ tabel $(0,05)$, maka $\mathrm{H}_{0}$ ditolak

2) Hipotesis Kedua

$\mathrm{H}_{0}=$ Tidak terdapat perbedaan hasil belajar peserta didik kelas XI IPA SMA Negeri 1 Majene yang dibelajarkan model pembelajaran berbasis masalah dengan inkuiri terbimbing.

$\mathrm{H}_{1}=$ Terdapat perbedaan hasil belajar peserta didik kelas XI IPA SMA Negeri 1 Majene yang dibelajarkan model pembelajaran berbasis masalah dengan inkuiri terbimbing.

Untuk pengujian statistiknya, hipotesis ini dirumuskan:

$\mathrm{H}_{0}: \mu_{3}=\mu_{4}$ lawan $\mathrm{H}_{1}: \mu_{3} \neq \mu_{4}$

Keterangan:

$\mu_{3}=$ nilai rata-rata hasil belajar peserta didik yang dibelajarkan model pembelajaran berbasis masalah.

$\mu_{4}=$ nilai rata-rata hasil belajar peserta didik yang dibelajarkan model pembelajaran inkuiri terbimbing.

Kriteria pengujian: Jika $\mathrm{p}$ hit $>\mathrm{p}$ tabel $(0,05)$, maka $\mathrm{H}_{0}$ diterima $\mathrm{p}$ hit $<\mathrm{p}$ tabel $(0,05)$, maka $\mathrm{H}_{0}$ ditolak

\section{HASIL DAN PEMBAHASAN}

a) Pembahasan Hasil Penelitian

Berdasarkan hasil penelitian yang telah diuraikan, pembahasan hasil penelitian ini meliputi pembahasan analisis deskriptif dan analisis inferensial yakni motivasi dan hasil belajar peserta didik. Pembahasan tersebut diuraikan sebagai berikut:

\section{Motivasi Belajar}

Berdasarkan hasil analisis deskriptif pretest dan posttest motivasi peserta didik, terlihat bahwa terdapat peningkatan nilai rata-rata motivasi belajar peserta didik pada kelas yang dibelajarkan model pembelajaran berbasis masalah yakni dari nilai rata-rata pretest motivasi sebesar $33,55 \%$ meningkat menjadi $69,50 \%$ dengan nilai rata-rata $N$-Gain motivasi belajarnya adalah 0,78 pada kategori tinggi. Sedangkan pada kelas yang dibelajarkan model pembelajaran inkuiri terbimbing dari nilai rata-rata pretest motivasi sebesar $34,73 \%$ meningkat menjadi $71,58 \%$ dengan nilai rata-rata $\mathrm{N}$ Gain motivasi belajarnya adalah 0,82 pada kategori tinggi. Peningkatan motivasi belajar kimia peserta didik yang dibelajarkan model pembelajaran inkuiri terbimbing lebih tinggi dari pada motivasi belajar peserta didik yang dibelajarkan model pembelajaran berbasis masalah. Walaupun demikian secara umum disimpulkan bahwa peningkatan motivasi belajar peserta didik pada kedua kelas eksperimen sama-sama berada pada kategori tinggi, hal ini menunjukkan bahwa kedua model pembelajaran yang digunakan sangat baik untuk meningkatkan motivasi belajar peserta didik.

Berdasarkan hasil analisis inferensial, untuk $N$-Gain motivasi belajar diperoleh $p$-value sebesar 0,095>0,05, menunjukkan bahwa peningkatan motivasi belajar pada keduanya tidak berbeda nyata. Hal ini disebabkan karena kedua model pembelajaran yang digunakan sama-sama berpusat pada peserta didik (student centered) dimana peserta didik lebih berperan aktif dalam proses pembelajaran. Penggunaaan model pembelajaran yang tepat pada setiap materi pelajaran merupakan suatu hal yang penting untuk dapat meningkatkan motivasi belajar peserta didik.

Materi sistem koloid merupakan materi yang sangat cocok untuk diterapkan model pembelajaran berbasis masalah karena materi sistem koloid kebanyakan ada disekitar kehidupan manusia, dan model pembelajaran berbasis masalah merupakan model pembelajaran berbasis faktual. Begitu pula dengan model pembelajaran inkuiri terbimbing juga cocok untuk materi sistem koloid, dimana peserta didik dengan bimbingan dari guru, peserta didik diarahkan menemukan sesuatu dari pertanyaan-pertanyaan yang muncul dari dalam diri peserta didik. Oleh 
karenanya kedua model pembelajaran yakni model pembelajaran berbasis masalah dan model pembelajaran inkuiri terbimbing sama-sama dapat meningkatkan motivasi belajar peserta didik pada materi sistem koloid.

2. Hasil Belajar

Berdasarkan hasil analisis deskriptif, untuk kelas yang dibelajarkan model pembelajaran berbasis masalah diperoleh nilai rata-rata pretest 7,27 dengan nilai tertinggi 16, sedangkan kelas yang dibelajarkan model pembelajaran inkuiri terbimbing diperoleh nilai rata-rata pretest 7,08 dengan nilai tertinggi 12 , hal ini menunjukkan bahwa kedua kelas tersebut memiliki kemampuan yang sama atau homogen sebelum diberi perlakuan. Hal ini sesuai dengan hasil pengujian homogenitas bahwa kedua kelas bersifat homogen.

Setelah diberi perlakuan terjadi peningkatan hasil belajar peserta didik yang terlihat dari rata-rata nilai posttest untuk kelas dibelajarkan model pembelajaran berbasis masalah sebesar 74,36 dan kelas yang dibelajarkan model pembelajaran inkuiri terbimbing sebesar 75,85 .

Berdasarkan kategori kriteria ketuntasan minimal (KKM) pada kelas yang dibelajarkan model pembelajaran berbasis masalah sebanyak 14 peserta didik yang mengalami ketuntasan sedangkan yang dibelajarkan model pembalajaran inkuiri terbimbing adalah 17 peserta didik yang mengalami ketuntasan. Jika dilihat dari nilai $N$-Gain pada kelas yang dibelajarkan model pembelajaran berbasis masalah sebesar 0,72 sedangkan kelas yang dibelajarkan model pembelajaran inkuiri terbimbing sebesar 0,74 , keduanya termasuk pada kategori tinggi, berarti kedua model pembelajaran yang digunakan sangat baik untuk meningkatkan hasil belajar peserta didik.

Persentase pencapaian hasil belajar dan nilai $N$-Gain peserta didik yang dibelajarkan model pembelajaran inkuiri terbimbing (eksperimen 2) lebih tinggi daripada peserta didik yang dibelajarkan model pembelajaran berbasis masalah (eksperimen 1), walaupun demikian berdasarkan hasil analisis inferensial, untuk $\mathrm{N}$-Gain hasil belajar diperoleh $p$ value sebesar $0,545>0,05$, berarti tidak menunjukkan perbedaan yang signifikan. Hal ini disebabkan karena pada kedua kelas eksperimen sama-sama menggunakan model pembelajaran yang berpusat pada peserta didik (student centered) dimana peserta didik lebih berperan aktif dalam proses pembelajaran. Model pembelajaran berbasis masalah menekankan peserta didik untuk menemukan masalah, merumuskan dan mencari jawaban dari masalah yang ditemukan dengan mencari informasi atau melakukan penyelidikan, biasanya masalah ini berhubungan dengan dunia nyata peserta didik. Sedangkan model pembelajaran inkuiri terbimbing, dengan bimbingan dari guru diharapkan peserta didik untuk terlibat aktif dalam proses pembelajaran yakni peserta didik ikut serta dalam mengajukan pertanyaan-pertanyaan, berusaha merumuskan jawaban sementara dan peserta didik melakukan penyelidikan untuk mencari jawaban dari pertanyaanpertanyaan tersebut, tahap akhir guru menganalisis proses inkuiri yang telah dilakukan peserta didik.

Kedua model pembelajaran dalam penelitian ini yakni model pembelajaran berbasis masalah dan model pembelajaran inkuiri terbimbing merupakan model pembelajaran yang hampir sama, kedua model pembelajaran ini berorientasi pada masalah. Hal yang membedakannya adalah pada model pembelajaran berbasis masalah, orientasi masalahnya berada ditahap awal inti pembelajaran dimana peserta didik diberikan wacana yang didalamnya mengenai seputar masalah yang berhubungan dengan dunia nyata, selanjutnya peserta didik merumuskan masalah dan melakukan penyelidikan untuk mencari tahu jawabannya. Sedangkan pada model pembelajaran 
inkuiri terbimbing, orientasi masalahnya berada pada tahap inti pembelajaran dimana peserta didik mengajukan pertanyaan-pertanyaan seperti: apa yang akan terjadi?, mengapa demikian? dll. Dari pertanyaan-pertanyaan tersebut, peserta didik berupaya merumuskan jawaban sementara dan mencari jawabannya dengan melakukan penyelidikan.

Pada kedua model pembelajaran berbasis masalah dan model pembelajaran inkuiri terbimbing terjadi proses pemrosesan informasi dengan berorientasi pada masalah. Hal ini sesuai dengan teori belajar Gagne dalam (Eveline \& Hartini, 2014) menjelaskan bahwa belajar tidak sekedar melibatkan hubungan antara stimulus dan respons, lebih dari itu belajar adalah melibatkan proses berpikir yang sangat kompleks yakni ilmu pengetahuan dibangun dalam diri seseorang melalui proses interaksi yang berkesinambungan dengan lingkungan. Jadi sebelum menerapkan model pembelajaran berbasis masalah maupun inkuiri terlebih dahulu seorang guru haruslah mengetahui kognitif peserta didik, hal ini sangat mempengaruhi keberhasilan suatu model pembelajaran. Hal ini sesuai dengan teori Jean Piaget mengatakan bahwa perkembangan kognitif bukan hanya hasil kematangan organisme, bukan pula pengaruh lingkungan semata, melainkan hasil interaksi keduanya (Sehe Y, 2011). Pentingnya kognitif yang harus dimiliki oleh peserta didik dalam kedua model pembelajaran ini yakni diterapkan pada awal pembelajaran dimana guru memberikan apersepsi seputar materi yang akan dipelajari dan juga pada inti pembelajaran dimana pada kedua model pembelajaran ini peserta didik mengumpulkan informasi yang berkaian dengan materi yang dipelajari diseputar permasalahan pada pembelajaran yang mereka hadapi.

Pada kedua model pembelajaran ini guru memberikan masalah kepada peserta didik dan peserta didik melakukan penyelidikan dari masalah tersebut sehingga peserta didik dapat menemukan masalah dan menemukan solusi dari masalah tersebut, hal ini sejalan dengan teori Bruner menjelaskan bahwa proses belajar akan berjalan dengan baik dan kreatif jika guru memberi kesempatan kepada peserta didik menemukan suatu aturan (termasuk konsep, defenisi dsb) melalui contoh-contoh yang menggambarkan (mewakili) aturan yang menjadi sumbernya. Adapun keuntungan belajar penemuan adalah menimbulkan rasa ingin tahu peserta didik, dapat memotivasi untuk menemukan jawabanjawaban dapat memecahkan masalah serta mengharuskan peserta didik untuk menganalisa dan memanipulasi informasi (Eveline \& Hartini, 2014).

Pada model pembelajaran berbasis masalah maupun inkuiri terbimbing, keduanya merupakan model pembelajaran yang menjadikan pembelajaran lebih bermakna, pembelajaran akan menjadi bermakna jika peserta didik mampu mengaitkan pengetahuan yang telah dimilikinya dengan materi pelajaran yang telah dipelajarinya itu, sesuai dengan teori belajar Ausubel bahwa peserta didik akan belajar dengan baik jika isi pelajaran (instructional content) sebelumnya didefenisikan dan kemudian dipresentasikan dengan baik dan tepat kepada peserta didik (advance organizers) oleh karenanya guru harus menyajikan materi pelajaran yang baru dan menguhubungkannya dengan konsep yang relevan yang sudah ada dalam struktur kognitif peserta didik (Eveline \& Hartini, 2014)

Penggunaaan model pembelajaran yang tepat pada setiap materi pelajaran merupakan suatu hal yang penting untuk dapat meningkatkan hasil belajar peserta didik. Khususnya pada materi sistem koloid, kedua model pembelajaran baik model pembelajaran berbasis masalah maupun model pembelajaran inkuiri terbimbing, sangat cocok untuk diterapkan pada materi sistem koloid. Hal ini karena materi sistem koloid merupakan salah satu 
materi kimia yang berkaitan dalam kehidupan sehari-hari.

Hasil penelitian ini sejalan dengan penelitian Ridha (2013) bahwa model pembelajaran berbasis masalah dapat meningkatkan motivasi dan hasil belajar biologi. Hasil penelitian yang dilakukan oleh Hadijah (2014) menyatakan bahwa model pembelajaran berbasis masalah dapat meningkatkan motivasi dan hasil belajar peserta didik. Sebagaimana juga penelitian yang dilakukan oleh Trisulsiati (2010) menyatakan bahwa model pembelajaran inkuiri dapat meningkatkan motivasi dan hasil belajar peserta didik.

\section{KESIMPULAN}

Berdasarkan hasil penelitian dan pembahasan, dalam penelitian ini dapat ditarik suatu kesimpulan sebagai berikut:

1. Besarnya peningkatan motivasi belajar peserta didik yang dibelajarkan model pembelajaran berbasis masalah adalah 0,78 pada kategori tinggi.

2. Besarnya peningkatan motivasi belajar peserta didik yang dibelajarkan model pembelajaran inkuiri terbimbing adalah 0,82 pada kategori tinggi.

3. Besarnya peningkatan hasil belajar peserta didik yang dibelajarkan model pembelajaran berbasis masalah adalah 0,72 pada kategori tinggi.

4. Besarnya peningkatan hasil belajar peserta didik yang dibelajarkan model pembelajaran inkuiri terbimbing adalah 0,74 pada kategori tinggi.

5. Tidak terdapat perbedaan peningkatan motivasi belajar yang signifikan antara peserta didik yang dibelajarkan model pembelajaran berbasis masalah dengan inkuiri terbimbing.

6. Tidak terdapat perbedaan peningkatan hasil belajar yang signifikan antara peserta didik yang dibelajarkan model pembelajaran berbasis masalah dengan inkuiri terbimbing.

\section{DAFTAR PUSTAKA}

Ali. M. 2004. Guru dalam Proses Belajar Mengajar. Bandung: Sinar Baru.

Arends, R.I. 2008. Learning to Teach Belajar untuk Mengajar. Yogyakarta: Pustaka Pelajar.

Djaali. 2007. Pengukuran dalam Bidang Pendidikan. Jakarta: Rineka Cipta.

Eveline \& Hartini. 2014. Teori Belajar dan Pembelajaran. Bogor: Ghalia Indonesia.

Hadijah, S. 2014. Peningkatan Motivasi, Aktivitas, dan Hasil Belajar Siswa Pada Materi Ekosistem Melalui Penerapan Model Pembelajaran Problem Based Learning kelas VIIf SMP Negeri 3 Palopo. Tesis. Tidak diterbitkan. Makassar: Pascasarjana Universitas Negeri Makassar.

Haling, dkk. 2004. Belajar dan Pembelajaran. Makassar: Badan Penerbit UNM.

Hanafiah M,N. \& Suhana C,M. 2009. Konsep Strategi Pembelajaran. Bandung: Rafika Aditama.

Jauhar, M. 2011. Implementasi PAIKEM dari Behavioristik sampai Konstruktivistik. Jakarta: Prestasi Pustaka.

Karim, A. 2010. Meningkatkan Motivasi dan Hasil Belajar IPA Fisika Melalui Pendekatan Pengajaran Quatum Setting Kooperatif Tipe STAD pada Siswa kelas VIIA SMPN 3 Palangga Kab. Gowa. Tesis. Tidak diterbitkan. Makassar: Pascasarjana Universitas Negeri Makassar.

Masyita. 2012. Eksplorasi. Proses Konstruksi Pengetahuan Matematika dalam Pembelajaran Kooperatif Tipe STAD Berdasarkan Gaya Kognitif Siswa Kelas VII MTSN Watampone. Tesis. Tidak diterbitkan. Makassar: Pascasarjana Universitas Negeri Makassar.

Ngalimun S. 2013. Strategi dan Model Pembelajaran. Yogyakarta: Aswaja Pressindo.

Nurlaelah. 2013. Komparasi Motivasi dan Hasil Belajar Antara Siswa yang Diajar dengan Media Lingkungan dan Media Gambar dalam Pembelajaran Matematika Pada 
Kelas IV SDN 42 Sinjai Selatan. Tesis. Tidak diterbitkan. Makassar: Pascasarjana Universitas Negeri Makassar.

Paul S. 2007. Metodologi Pembelajaran Fisika. Yogyakarta: Universitas Sanata Dharma.

Ridha Y, 2012. Perbandingan Motivasi dan Hasil Belajar Biologi Siswa SMA yang Diajar dengan Menggunakan Model Pembelajaran Share dan Model Pembelajaran Berbasis Masalah. 2013. Tesis. Tidak diterbitkan. Makassar: Pascasarjana Universitas Negeri Makassar.

Roestiyah, N.K. 2008. Strategi Belajar Mengajar (Salah Satu Unsur Pelaksanaan Strategi Belajar Mengajar: Teknik Penyajian). Jakarta: Rineka Cipta.

Rusman. 2014. Model-Model Pembelajaran. Jakarta: Rajawali Pers.

Sagala, S. 2009. Konsep dan Makna Pembelajaran. Bandung: Alfabeta.

Sanjaya, W. 2010. Strategi Pembelajaran Berorientasi Standar Proses Pendidikan. Jakarta: Kencana.

Sardiman A.M. 2008. Interaksi dan Motivasi Belajar Mengajar. Jakarta: Raja Grafindo Persada.

Savery, J.R. 2006. Overview of Problem-based learning: Definitions and Distinctions. Interdisciplinary Journal of Problembased Learning, 1(1), 9-20.

Sehe, Y. 2011. Pengembangan Perangkat Pembelajaran Kimia Berbasis Masalah (Studi Pada Materi Pokok Larutan Penyangga). Tesis. Tidak diterbitkan. Makassar: Pascasarjana Universitas Negeri Makassar.

Slameto. 2003. Belajar dan Faktor-Faktor yang Mempengaruhinya. Jakarta: Rineka Cipta.

Sudarmo, U. 2013. Buku Kimia Kelas XI Peminatan MIPA. Jakarta: Erlangga.

Sugiyono. 2010. Metode Penelitian Kuantitatif, Kualitatif dan $R \& D$. Bandung: Alfabeta.

Sumiati \& Asra. 2008. Metode Pembelajaran. Bandung: $\mathrm{CV}$ Wacana Prima.
Suprijono, A. 2012. Cooperative Learning. Yogyakarta: Pustaka Pelajar.

Suyanti, R.D. 2010. Strategi Pembelajaran Kimia.Yogyakarta: Graha Ilmu.

Syah, M. 2005. Psikologi Belajar. Jakarta: Raja Grafindo Persada.

Trianto, 2011. Model-Model Pembelajaran Inovatif Berorientasi

Konstruktivistik. Jakarta: Prestasi Pustaka.

Trianto, 2012. Mendesain Model Pembelajaran Inovatif Progresif. Jakarta: Kencana.

Trisulsiati. 2010. Peningkatan Motivasi dan Hasil Belajar Fisika Melalui Pendekatan Pembelajaran Penemuan Terbimbing. Tesis. Tidak diterbitkan. Makassar: Pascasarjana Universitas Negeri Makassar.

Wena, M. 2013. Strategi Pembelajaran Inovatif Kontemporer. Jakarta: Bumi Aksara.

Yanti. 2014. Pengaruh Model Pembelajaran Kooperatif Tipe Teams Games Tournament (TGT) Terhadap Kemandirian Belajar dan Peningkatan Kemampuan Penalaran dan Koneksi Matematik Peserta Didik SMPN 1 Kota Tasikmalaya. Jurnal Pendidikan dan Keguruan Vol.1 No.1, artikel 2. 